\title{
Authors of Articles in Vol. III, No. 2
}

H. LEEMING, Reader in Comparative Slavonic Philology, School of Slavonic and East European Studies, University of London.

G. Y. SHEVELOV, Professor of Slavic Languages, Columbia University, New York.

A. B. McMILLIN, Lecturer in Russian Language and Literature, School of Slavonic and East European Studies, University of London.

P. J. MAYO, Lecturer in Russian, University of Sheffield.

R. D. SUSSEX, Senior Lecturer in Linguistics, University of Monash, Melbourne. 